\title{
Carrots and Other Horticultural Crops as a Source of Provitamin A Carotenes
}

\author{
Philipp W. Simon \\ Agricultural Research Service, U.S. Department of Agriculture, Department of \\ Horticulture, University of Wisconsin-Madison, Madison, WI 53706
}

\begin{abstract}
Horticultural crops are the main world source of vitamin A. in the form of provitamin A carotenes. Since world vitamin A deficiency is the most common specific dietary deficiency (Pitt, 1979), improvement of horticultural crop nutritional quality and productivity and increased consumption of horticultural crops can make an important contribution to improved human health.
\end{abstract}

\section{World vitamin A consumption}

It has been estimated that. each year, 8 to 10 million children suffer vitamin A deficiency. With this, mucosal epithelial cells de teriorate to increase the risk of respiratory infection, diarrhea, and other communicable disease 2- to 3-fold. Furthermore, 1 million children (especially 6-month- to 6-year-olds) suffer severe vitamin A-deficiency eye disease, (xerophthalmia), 250,000 of these lose their sight, and 150.000 of these die within several months of becoming blind (USAID, 1989). The greatest incidence of vitamin A deficiency occurs in Africa, Asia, and parts of Latin America and the Near East. Although eye disease due to vitamin A deficiency is rare in developed areas, it is thought that $30 \%$ of the U.S. population is "at risk", since $<70 \%$ of the recommended daily allowance of vitamin A is consumed (USDHEW, 1968-70; Briggs, 1981). Furthermore, carotene and vitamin A consumption also have been associated with a significant reduction in the incidence of cancer (e.g., Halter. 1989, Ziegler, 1989). Thus, vitamin A and provitamin A carotenoids affect several diverse aspects of human health (Bendich and Olson, 1989).

The daily vitamin A intake recommended by the FAO is 250 to 400 retinol equivalents (RE) for children. 575 to $725 \mathrm{RE}$ for adoles cents. and $750 \mathrm{RE}$ for adults (higher for pregnant and lactating women) (FAO, 1982). The food supply of retinol equivalents in 198686 provided 803 RE per caput per day worldwide. Yet the daily per caput supply was $90 \%$ of the recommended adult intake (675 RE) for developing countries overall $(75.4 \%$ of the world population), <500 RE in 30 countries, <400 RE in 18 countries, and $<300 \mathrm{RE}$ in 11 countries (FAO, 1988). Most of the countries with a markedly deficient retinol supply are in Africa, where the average retinol availability has dropped slightly since 1969-71. In Malawi, Swaziland, Zambia, and Zimbabwe, retinol availability has dropped $10 \%$ to $18 \%$ in this time period. This is in contrast to Asian countries with historically low retinol availability, where supplies have generally risen since 1961-64. in some cases dramatically (e.g., Indonesia. Malaysia. Pakistan, and Saudi Arabia). Several Central and South American countries also have experienced a reduction in retinol supply since 1961-64 (e.g., Ecuador, Peru, Guyana, and Guatemala), whereas several Caribbean island nations have demon strated significant increases. 
As others have pointed out (e.g., Simpson, 1983). the retinal supply tends to come from vegetable sources in developing and often deficient areas. Since 1961-63. 83\% to $84 \%$ of the retinal came from fruits and vegetable products. the rest from meat and animal products, in developing areas (Table 1). Only $48 \%$ to $49 \%$ of the retinol was from fruits and vegetables in developed areas (FAO, 1988). Thus, increased intake of provitamin A carotenes from available horticultural crops could play a significant role in reduc ing the incidence of world vitamin A deficiency. Increased carotene intake also could reduce the risk of cancer in both developed and developing areas.

\section{Sources of provitamin A carotenes}

Provitamin A carotenes account for the yellow, orange. or red color in many vegetables and fruits (Table 2); they also occur with chlorophyll in all green plant tissues. Only plants synthesize carotenoids, and several different carotenoids always occur when they are present. Since many carotnoids are not vitamin A precur sors. earlier values published for carotene content in fruits and veg etables tended to be inflated. With the development of high-performance liquid chromacographic methods for quantifying individual carotenes. more-accurate estimates of provitamin A capacity are able to be made and current estimates tend to be lower (Table 2) (Gebhardt et al.. 1982; Simpson. 1983; Haytowitz and Matthews, 1984). In contrast to this general trend. carotene values for carrot, sweetpotato. and squash arc higher than earlier values. since new darker-orange cultivars are now available (Putnam. 1989).

The fruits and vegetables listed in Table 2 represent only 3 small subset of those conraining carotenes. These were selected because they contain at least $1 \mathrm{ppm}$ provitamin A carotenes and they are produced in high enough quantity to appear in FAO agricultural production statistics (e.g.. FAO. 1988). Also included for compari son are broccoli, parsley, spinach, and lettuce. It should be noted that, except for maize and sweetpotatoes, none of the widely grown crops that serve as major sources of dietary calories and protein (rice, wheat. potatoes, cassava sorghum, dry pulses, millet. yams) contain significant levels of provitamin A carotenes.

The availability of high-carorene horticultural crops is one indication of the horticultural contribution to world vitamin A status. Availability in developing counties is increasing for nearly all horticultural commodities that contain carotenes (Table 3).

One major exception to this trend is sweetpotatoes. for which per caput supply has decreased $29 \%$ in developing countries since 1961-65. Contrary to all other carotenecontaining commodities, sweetpotato-per-caput supply also has reduced dramatically in developed areas over this time (FAO, 1988). When orange-colored cultivars are grown in developing areas, sweetpotatoes have been a very important source of dietary retinol. The trend toward greater per-caput availability of retinol in Asia (Table 1) suggests that the increased availability of other provitamin A carotene sources is counteracting diminishing sweetpotato supply.

Caution must be exercised in drawing conclusion about vitamin A status from food availability since these statistics fail to consider consumption, absorption. and use, which may be confounded by fat intake, fever, diarrhea, and other factors. Vitamin A deficiency symptoms can occur even with adequate consumption of provitamin A-rich foods (Tarwotjo et al., 1982). Furthermore, availability may be a poor reflection of local consumption when crops are grown for export markets. Horticultural commodities often end up in local, national, or international markets to further confound estimates of intake based on supply.

In addition to sweetpotato, red palm oil is the other significant source of provitamin A carotenes in many developing areas. Although unavailable in developed nations, local differences in red palm oil consumption are well-correlated with the incidence of vitamm A deficiency in Africa (Carter and Cook. 1963; Thompson, 1965). Red palm oil availability has risen 7-fold per caput in Asia and 4-fold in all developing areas since 1961-65. Crude palm oil carotene content varies from 300 to $2560 \mathrm{ppm}$. but, unfortunately, from a nutritional standpoint, palm breeders select for low carotene concern so that palm oil can compete in a world market with other wise colorless oils. Refuting processes further reduce carotene content (Hartley, 1988).

\section{Increasing the supply of provitamin A carotenes with nontradi - tional crops and dark-green leafy vegetables}

The availability of provitamin A-rich horticultural crops that were, in 1961-65. nontraditional. has increased in most developing areas (Table 3). Dietary diversification to include European and Western crops such as carrots and tomatoes in Africa and Asian diets, or carrots and the originally African palm oil in Central and South America diets, may have played an important role in increas ing available carotene and retinol supplies. Thus, a case can be made for introducing or expanding the use of nontraditional crops to diversify and fortify diets. However. the introduction of new crops must be gradual to avoid social resistance. Furthermore, growing and postharvest storage conditions must be appropriate be fore these crops can be produced successfully.

The production of nontraditional crops can create an incentive for greater productivity, since these crops are often more profitable in the market. Unfortunately, market profitability can compete with the improvement of local nutritional status since profitable crops tend to be sold rather than consumed locally. However, this did not occur with Indonesian mango production. where children consumed

Table 1. Contribution of vegetable carotenoids to world vitamin A supply.

\begin{tabular}{|c|c|c|c|c|c|}
\hline Region & $1961-63$ & $1969-71$ & $1979-81$ & $1984-86$ & Change $(\%)^{z}$ \\
\hline World & $2807(68)^{y}$ & $2975(68)$ & $3158(69)$ & $3384(69)$ & +2.1 \\
\hline Africa & $4039(81)$ & $4118(81)$ & $4090(80)$ & $4029(80)$ & -0.2 \\
\hline North/Central America & $2409(47)$ & $2442(48)$ & $2743(52)$ & $2864(53)$ & +19 \\
\hline South America & $1691(50)$ & $1782(50)$ & $1788(46)$ & $1963(50)$ & +16 \\
\hline Asia & $2760(88)$ & $2889(87)$ & $3134(86)$ & $3401(86)$ & +23 \\
\hline Europe & $3058(47)$ & $3513(48)$ & $3620(46)$ & $3949(42)$ & +29 \\
\hline Oceania & $2882(40)$ & $3232(43)$ & $3282(46)$ & $3708(52)$ & +29 \\
\hline Soviet Union & $2332(46)$ & $2615(46)$ & $2681(45)$ & $3007(46)$ & +29 \\
\hline Developed countries & $2774(48)$ & $3107(48)$ & $3248(48)$ & $3490(49)$ & +26 \\
\hline Developing countries & $2823(84)$ & $2921(84)$ & $3126(84)$ & $3348(83)$ & +19 \\
\hline
\end{tabular}

${ }^{2}$ Change in beta-carotene equivalent supply 1961-63 to $1984-86$.

${ }^{\mathrm{y}}$ Beta-carotene equivalent in micrograms per caput per day from vegetable sources (percent contri-bution to total retinol equivalent supply); from FAO (1988). 
Table 2. Carotene content of selected raw fruits and vegetables (ppm). ${ }^{\mathrm{Z}}$

\begin{tabular}{|c|c|c|c|c|c|c|}
\hline \multirow[b]{2}{*}{ Fruitvegetable } & \multicolumn{6}{|c|}{ Reference ${ }^{y}$} \\
\hline & A & B & $\mathrm{C}$ & $D$ & $E$ & $F$ \\
\hline Red paim oil & $7-252$ & $\cdots$ & -- & $\cdots$ & 120 & $500-1600^{x}$ \\
\hline Canrot & 72 & 66 & 169 & 39 & 120 & $70(14-122)$ \\
\hline Parsley & 49 & 51 & 31 & 60 & -- & 60 \\
\hline Spinach & 57 & 48 & 40 & 57 & --- & $60^{w}(50-70)$ \\
\hline Sweetpotato & $1-46$ & 47 & 120 & $1-17$ & 1 & $40^{w}(0-150)$ \\
\hline Pumpkin & 20 & 38 & 10 & $0-22$ & $\cdots$ & $14^{w}(11-60)$ \\
\hline Mango & 38 & 29 & 23 & 18 & 32 & $1-60$ \\
\hline Pepper, red & - & 27 & 8 & $\ldots$ & 28 & $127-248$ \\
\hline Muskmelon & 20 & 20 & 19 & 6 & -.. & $11-120$ \\
\hline Broccoli & 21 & 15 & 9 & $5-8$ & $-\cdots$ & $4-25^{w}$ \\
\hline Apricot & 17 & 15 & 16 & 13 & $\ldots$ & $6-19$ \\
\hline Papaya & 11 & 10 & 12 & -- & 10 & --- \\
\hline Plum & 2 & $1-2$ & 2 & $1-5$ & 8 & 2 \\
\hline Peach & 5 & 8 & 3 & 1 & -.. & $5(3-15)$ \\
\hline Squash & $2-30$ & $2-6$ & $1-47$ & $1-5$ & $\ldots$ & $4-36$ \\
\hline Letruce & $3^{v}$ & $2^{v}$ & 2 & 13 & 2 & $2-10$ \\
\hline Pepper, green & 4 & 3 & 3 & $3-7$ & 2 & $9-11$ \\
\hline Plantain & $0-7$ & $0-7$ & - & 4 & 8 & -.. \\
\hline Tomaro & 7 & 5 & 7 & 5 & 5 & $5(3-60)$ \\
\hline Green bean & 4 & 3 & 4 & 2 & 2 & 4 \\
\hline Green pea & 4 & 2 & 4 & 4 & - & 3 \\
\hline Pineapple & $<1$ & $<1$ & $<1$ & $\cdots$ & $<1$ & $<1$ \\
\hline Cabbage & $1^{0}$ & 1 & $1^{u}$ & 1 & -.. & 3 \\
\hline Sweet com & 2 & 1 & 2 & $\ldots$ & 1 & $2(1-5)$ \\
\hline Tangerine & 2 & 3 & 5 & --- & 2 & $\begin{array}{l}2(1-J) \\
1\end{array}$ \\
\hline Orange & 1 & $1-2$ & 1 & $3-8$ & 2 & $0.2-6$ \\
\hline Banana & 2 & 1 & $<1$ & $<1$ & 1 & $0.3-2$ \\
\hline
\end{tabular}

${ }^{\mathrm{z}}$ Values reflect total carotenoid content from refs. A, B, D, E, and F. equivalent beta-carotene content fron ref. C.

${ }^{\mathrm{y}} \mathrm{A}=$ Watt and Merril (1950) (United States) and Leung et al. (1952) (Far East); B = Adams (1972) (United States); C = Gebhardt et al. (1982) and Haytowitz and Matthews (1984) (United States); D = Polacchi et al. (1982) Wear East): E = Latham (1979) (Africa; and F = Klaui and Bauemfiend (1981).

${ }^{\mathrm{x}}$ Unrefined.

${ }^{\mathrm{w}}$ Cooked.

vThree- to 5-fold higher for butterhead and cos.

${ }^{\mathrm{u}} \mathrm{S}$ eventeen parts per million for Chinese cabbage.

Table 3. Supply of selected carotene-containing horticultural commodities to developing countries. ${ }^{\mathrm{z}}$

\begin{tabular}{|c|c|c|c|c|c|}
\hline \multirow[b]{2}{*}{ Crop } & \multicolumn{4}{|c|}{ Year } & \multirow[b]{2}{*}{ Change $^{y}(\%)$} \\
\hline & $1961-65$ & $1969-71$ & $1979-81$ & 1988 & \\
\hline Red palm oil & 0.62 & 0.76 & 1.53 & 2.33 & +276 \\
\hline Carrot & 0.56 & 0.67 & 0.86 & 1.08 & +93 \\
\hline Sweetpotato & 46.82 & 41.47 & 40.26 & 33.06 & -29 \\
\hline $\begin{array}{l}\text { Squash Pump- } \\
\text { kin \& gourds }\end{array}$ & & & & & \\
\hline $\begin{array}{l}\text { Kin, \& gouros } \\
\text { Mango }\end{array}$ & $\begin{array}{l}1.12 \\
4.82\end{array}$ & $\begin{array}{l}1.15 \\
4.70\end{array}$ & $\begin{array}{l}1.13 \\
2.53\end{array}$ & $\begin{array}{l}1.14 \\
2.42\end{array}$ & $\begin{array}{l}+2 \\
-50\end{array}$ \\
\hline Pepper & 0.89 & 1.14 & 1.32 & 1.50 & +69 \\
\hline Muskmelon, & & & & & \\
\hline other melons & 1.14 & 1.06 & 1.28 & 1.41 & +24 \\
\hline Apricot & 0.15 & 0.15 & 0.20 & 0.24 & +60 \\
\hline Papaya & --- & 0.44 & 0.63 & 0.93 & +111 \\
\hline Plum & 0.18 & 0.28 & 0.30 & 0.38 & +111 \\
\hline nectarine & 0.31 & 0.50 & 0.51 & 0.57 & +84 \\
\hline Plantain & 6.09 & 6.17 & 7.06 & 6.18 & +2 \\
\hline Tomaro & 4.24 & 4.75 & 6.19 & 7.62 & +80 \\
\hline Green bean & 0.14 & 0.25 & 0.36 & 0.39 & +178 \\
\hline Green pea & 0.17 & 0.26 & 0.25 & 0.25 & +47 \\
\hline Cabbage & 2.45 & 2.93 & 3.87 & 3.71 & +51 \\
\hline Tangerise & 0.40 & 0.58 & 0.79 & 0.90 & +125 \\
\hline Orange & 4.01 & 4.75 & 6.83 & 8.17 & +103 \\
\hline
\end{tabular}

${ }^{7}$ Kilograms per caput per year (FAO. 1988).

${ }^{\mathrm{y}} 1961-65$ to 1988 . mangoes routinely, even though mango production was developed for export markets (Tarwotjo et al., 1982).

Dark green leafy vegetable can be high in provitamin A carotenes, and many are readily available locally in developing areas (e.g., Klaui and Bauernfiend. 1981). Nutrition education programs in these areas also should consider encouraging production and consumption of deep orange tubers, storage roots, and fruits that are typically more palatable and suitable for long storage than are leaves.

Increasing provitamin A carotene supply with plant breeding

In comparison to storage carbohydrates and protein, carotenes are not necessary for plant growth in non-green tissues and they ac count for a relatively small fraction of plant dry weight. Consequently, greater genetic variation is observed for provitamin A carotene content than for storage carbohydrate or protein content. Breeding for increased provitamin A carotene content without adversely affecting culinary quality has been successful for tomatoes (Tigchelaar, 1988), sweetpotatoes (Collins, 1988). and carrots (Laferriere and Gabelman. 1968. Simon, 1988). where content of beta-carotene equivalent up to $50 \mathrm{ppm}$ (Tomes, 1958), $170 \mathrm{ppm}$ (Collins, 1988). and 500 ppm (Simon et al., 1989). respectively, has be-en obtained in select genetic stocks of these crops.

Although straightforward, plant breeding is not always an effective way to increase provitamin A availability. In some areas, local preferences demand white-colored melons, squash, yams, sweetpotatoes, and maize, thereby limiting the use of carotene-rich culti- 
vars (Munger, 1988). The demand for red (high-lycopene) rather than dark orange (high-beta-carotene) tomatoes has greatly impeded the use of dark orange tomatoes (Tigchelaar, 1988). Although yarns with up to $14 \mathrm{ppm}$ carotenes (Martin and Ruberts. 1975). cauliflower with 3 ppm carotenes (Dickson et al.. 1988). and cucumber with $6 \mathrm{ppm}$ carotenes (Simon, unpublished data) have been selected. the usefulness of these typically carotene-free horticultural commodities in contributing to increased provitamin A consumption is yet unproven.

In addition to breeding directly for increased carotene content. genetic improvement of flavor or cooking quality also can stimulate an increased overall consumption. thereby increasing provitamin A consumption. Similarly, improved pest resistance and adaptation to areas or seasons not typically used for crop production can increase availability (Munger, 1988; Simon, 1988; Tigchelaar, 1988).

\section{High-carotene carrots to improve vitamin A status-a case study}

Carrots are grown world-wide, although generally not as a major dietary staple. Orange cultivars are used in all areas. sometimes in conjunction with white or purple cultivars. In an effort to provide additional provitamin A carotenes to deficient areas of the world. the 'Beta III' carrot was developed (Peterson et al.. 1988; Simon, 1988).

Roots of 'Beta III' contain 270 ppm carotene, making it somewhat darker orange, but otherwise typical of the thin-rooted American 'Imperator' type, which contains 80 to 120 ppm carotenes. Culinary quality was not reduced by increasing carotene content. International field trials of 'Beta III' conducted from 1986 to 1989 have generally been successful (Table 4). Seed samples were sent to countries covering a wide geographic range. Typically one or two (up to four) cooperators responded for each country. Of the 31 countries reporting the performance of 'Beta III' in their tri als, 25 indicated acceptable productivity, adaptation. flavor, and appearance. Four countries reported suitable flavor and adaptation for their conditions, but noted that the roots of this cultivar are too thin or small. This is not unexpected, since cooperators in these countries. and many satisfied with 'Beta III' performance. indicated that their typical cultivars are the thicker-rooted 'Chantenay', 'Danvers'. or 'Nantes' types, instead of the thinner 'Imperator' type common to the United States.

These results indicate that high-carotene carrots developed in the United States are generally acceptable for most world consumers and that it is not necessary to develop cultivars adapted to specific climatic regions. However, since the thin-rooted 'Imperator' carrot is not common outside of the United States or Canada, highcarotene carrots for international use may be more widely accepted if thick-rooted. Improved flavor and higher carotene content [ $>600$ ppm (Simon and Wolff. 1987; Simon et al.. 1989)) are other desir able attributes to help fulfill the needs of world carrot consumers.

Two cooperators found no germination in seed planted (Table 4). Failure of carrot seed to germinate is a difficult problem to rem edy in warm and/or humid areas. where vitamin A deficiency is prevalent. Water-proof seed packaging can provide some protec tion. Local seed production also can assure fresher and more readi ly available seed. However. the need for most carrot cultivars to be exposed to consistently cool night temperatures $(<10 \mathrm{C})$ for 1 to 2 months to initiate flowering limits the possibility of local seed pro duction to upland regions in many parts of the world. Certain carrot cultivars will flower in warmer environments. This suggests that local carrot seed production may be feasible in areas where it is not accomplished now.

Carrot root production also tends to be in upland tropical areas since carrot is a cool-season crop. The lack of cultivars adapted to the lowland tropics is a major impediment to the use of carrots and several other high-carotene horticultural crops in certain vitamin Adeficient parts of the world (Munger, 1988). The possibility of de veloping carrots for lowland tropical production can only be tested
Table 4. Summary of 'Beta III' carrot performance in international trials.
Country

Cameroon. Ghana. Ivory Coast. Kenya. Lesotho. Madagascar. Malawi, Mali, Niger, Rwanda. Zinbabwe. Bolivia, Brazil. Chile, Guatemala, Mexico, Panama. Peru. People's Republic of China. India, Indonesia. Iran, Nepal. Pakistan, Philippines

Nigeria, South Africa. Montsenat. Syria

Djibouti. Sri Lanka
Response

Productivity, adaptation, flavor, and appearance satisfactory

Adaptation and flavor satisfactory; roots too thin or small

Seed did not germinate by establishing field trials to evaluate breeding stocks in these areas.

Horticultural approaches to reduce vitamin A deficiency have been suggested to complement medical intervention, food fortification, nutrition education. and socioeconomic measures (Arroyave et al., 1977), To completely fulfill adult vitamin A needs with highcarotene carrots, $\approx 30 \mathrm{~g}$ of 'Beta III' carrot roots/day, or $11 \mathrm{~kg} / \mathrm{year}$ (140 to 150 average roots) would be required. The cost of carrot seeds to meet this need is U.S.\$0.03-0.05 plus packaging costs. Thus, carrots, and other horticultural crops, offer a relatively inex pensive and readily sustainable approach to help alleviate world vi tan-tin A deficiency.

\section{Literature Cited}

Adams, CF. 1975. Nutritive value of American foods. USDA Hdbk. 456. Arroyave. G., J.C. Bauemfiend, J.A. Olson, and B.A. Underwood. 1977. Selection of intervention strategies. Intl. vitamin A consultative group Rpy.. guidelines for the eradicatim of vitamin A deficiency and xerophthlmia. Nutrition Found., New York.

Bendich. A. and J.A. Olson. 1989. Biological actions of carotenoids. FASEB J. 3: 1927-1932.

Briggs, M.H. 1981. Vitamins in human biology and medicine, CRC Press, Boca Raton, Fla.

Carter, R.S. and G.C. Cook. 1963. Studies on the serum total carotenoids. vitamin A. and serum color in Nigerian soldiers. Brit J. Nutr. 17:515522.

Collins, W.W. 1988. Genetic improvement of sweet potatoes for meeting human nutritional needs. p. 191-199. In: B. Quebedeaux and F.A. Bliss (eds.). Horticulture and human health. Prentice Hall, Englewood Cliffs, NJ.

Dickson, M.H., C.Y. Lee. and A.E. Bramble. 1988. Orangecurd high carotene cauliflower inbreds. NY156, NY163, and NY165, HortScience 23:778-779.

FAO, 1982. Management of group feeding programs, FAO, United Nations, Rome, FAO Food and Nutrition Paper 23.

FAO, 1988. Agriculture production yearbook, FAO, United Nations. Rome. FAO Stat. Ser. 82

Gebhardt, S.E.. R. Cutrufelli, and R.H. Matthews. 1982. Composition of foods: Fruits and fruit juices. USDA Hdbk. 8-9.

Halter, S. 1989. Vitamin A: Its role in chemoprevention and chemotherapy of cancer. Human Pathol. 20:205-209.

Hartley. CWS. 1988. The oil palm. Longman, London.

Haytowitz. D.B. and R.H. Matthews. 1984. Composition of foods: vegetbles and vegetable products. USDA Hdbk. 8-11.

Laferricre, L and W.H. Gabelman. 1968. Inheritance of color total carotenoids. alpha-carotene. and beta-carotene in carrots. Daucus carota L Proc. Amer. Soc. Hort. Sci. 95:408-418.

Leung, W.-T.W.. R.K. Pecat, and B.K. Watt 1952. Composition of foods used in far eastern countries. USDA Hdbk. 34

Martin, F.W. and R. Ruberte. 1975. Carotenoid pigments of Dioscorea cayenensis. Ann. Applied Biol. 80:3 17-322.

Munger, H. 1988. Adaptation and breeding of vegetable crops for improved human nutrition, p. 177-184. In B. Quebedeaux and F.A. Bliss (eds.). Horticulture and human health Prentice Hall. Englewood Cliffs. NJ. 
Pitt, B.A.J. 1979. Vitamin A deficiency and excess. The importance of vitamins to human health. University Park Press, Baltimore.

Peterson C.E.. P.W. Simon. V.E. Rubatsky, and J.O. Strandberg. 1988. Beta III Carrot. HortScience 23:917.

Polacchi. W.. J.S. McHargue, and B.P. Perloff. 1982. Food composition tables for the Near East. FAO. United Nations. Rome. FAO Food and Nutrition Paper 26.

Putnam, J.J. 1989. Food consumpion. prices, and expenditures. 1986-7. USDA Stat Bul. 773.

Simon, P.W. 1988. Genetic improvement of carrots for meeting human nutritional needs, p. 208214. In: B. Quebedeaux and F.A. Bliss (eds.). Horticulture and human health. Prentice Hall, Englewood Cliffs, NJ.

Simon. P.W., X.Y. Wolff, C.E. Peterson, D.S. Kammerlohr. V.E. Rubatzky. J.O. Strandberg. M.J. Basset and J.M. White. 1989. High carotene mass carnx population. HortScience 24:174-175.

Simon, P.W. and X.Y. Wolff. 1987. Carotenes in typical and dark orange carms. J. Agr. Food Chem. 35:1017-1022.

Simpson. K.L 1983. Relative value of the carotenoids as precursors of vitamin A. Proc. Nutr. Soc. 42:7-17.
Tarwotjo. I., A. Sommcr. T. Soegiharto. D. Susanto, and Muhilal. 1982. Dietary practices and xerophthalmia among Indonesian children. Amer. J. Clin. Nutr. 35:575-581.

Thompson, S.Y. 1965. Origin, distribution. and absorption of provitamin A. Proc. Nutr. Soc. 24:136-146.

Tigchelaar. E.C. 1988. Genetic improvements of tomato nutritional quality, p. 185-190. In: B. Quebedeaus and FA. Bliss (eds.). Horticulture and human health. Prentice Hall, Englewood Cliffs, N.J.

Tomes, M. 1958. 'Cam-Red'. a new provitamin A-rich tomato. Econ. Bot. 12:256-260.

U.S. Agency for International Development 1989. Vitamin A field support component of the vitamin A for health project 936-5116.

U.S. Department of Health. Education, and Welfare. Ten-State Nutritional Survey 1968-70. IV Biochemical Dept. HEW Publ. HSM 72-8132.

Watt, B.K. and A.L Merrill. 1950. Composition of foods-raw, processed, and prepared. USDA Hdbk. 8.

Ziegler. R.G. 1989. A review of epidemiologic evidence that carotenoids reduce the risk of cancer. J. Nutr. 119:116-122. 